\title{
The Effect of Primary School Teachers' Experiences on the Signification of Their Pedagogical Work as a Result of the Consequences of the Economic Crisis in Their Everyday Reality
}

\author{
Gerasimos S. Koustourakis \\ Associate Professor \\ Department of Educational Sciences and Early Childhood Education \\ University of Patras \\ University Campus, 265.04 Rio Patras, Greece \\ Anna Asimaki \\ Assistant Professor \\ Department of Primary Education \\ University of Patras, Greece \\ Theodora Giachali \\ Postgraduate Student \\ Department of Educational Sciences and Early Childhood Education \\ University of Patras, Greece
}

\begin{abstract}
The aim of this paper is to investigate, using concepts from the theory of Alfred Schutz, the lived experiences of teachers in Greek primary education in terms of the consequences of the economic crisis on their everyday reality, and the meaning they attach to their educational-pedagogical work in comparison with the pre-crisis period. The research was carried out during the 2016-2017 school year using semi-structured interviews. The sample was made up of 20 teachers from public primary schools in Patras. The most significant findings of the research revealed that the teachers' lived experiences of the consequences of the economic crisis in their everyday reality were defined by the cut in their salary, the reduction in their buying power and the creation of economic and social problems and difficulties within their families. Moreover, it emerged that the economic crisis did not affect their educational-pedagogical work in comparison with the pre-crisis period.
\end{abstract}

Keywords: Classroom space, kindergartens, teachers, pupils, corners, instructional rules, regulative rules

\section{Introduction}

The economic crisis which began with the bankruptcy of the Lehman Brothers bank in 2007 caused a global financial crisis. Since 2008 this crisis has created many problems in the everyday reality of European citizens (Ötker-Robe \& Podpiera, 2013). The countries of Southern Europe (Portugal, Greece, Spain, Cyprus, Italy) were hit harder by the global economic crisis resulting in the increase in poverty and social inequality, as well as the reduction of public funding for education and health (Poeschl, Valentim, \& da Silva, 2015).

At the start of the $2^{\text {nd }}$ decade of the $21^{\text {st }}$ century Greece went through the most painful economic crisis in its recent history. So, facing the threat of financial collapse, it accepted financial aid from the European Commission, the European Bank and the International Monetary Fund. The results of economic austerity become evident to the Greek population with the increase in poverty, the rise in unemployment, the reductions and cuts in wages and pensions, as well as the rapid increase in taxes (Matsaganis \& Leventi, 2014; Vasilopoulou, Halikiopoulou, \& Exadaktylos, 2014). Meanwhile, austerity contributed to the increase in suicides and mental illness (Zavras, Tsiantou, Pavi, Mylona, \& Kyriopoulos, 2013).

The institution of education in Greece during the economic crisis is influenced significantly by the shrinking of public spending (Chalari, 2016a.). So, educational reality is characterised by mergers and closures of school units, while at the same time shortages of equipment and in the material infrastructure of the schools grow (Hatziparadeisi, 2017). 
The economic recession affects the daily life of the pupils since, due to the economic difficulties their families face, they are unable to participate in the school's educational activities (educational excursions and visits) while there are a good number of cases where children display a reduced school performance (Kakana, Garagouni-Araiou, Theodosiou, Manoli, Mavidou, Rousi-Vergou, Chatzopoulou, Androusou, Avgitidou, \& Tsafos, 2016). In addition, the residues of austerity are evident as much in the mental as in the emotional health of the pupils (Magaliou \& Haniotakis, 2014). Research findings show that the material deprivation index is especially high in Greece and as a result the pupils' families are unable to meet their basic life needs (Akrivou, Bonoti, \& Dermitzaki, 2016; Papatheodorou \& Papanastasiou, 2017).

Research findings on the impact of the economic crisis on greek primary school teachers revealed salary cuts, the reduction in their spending power, the increasing economic difficulties that affect their family life as well as the restriction of social activities with friends (Chalari, 2016b). In addition, research studies depict the professional burnout and anxiety teachers experience, as well as the impact that the reductions and cuts in their salary have on their teaching work (Botou, Mylonakou-Keke, Kalouri, \& Tsergas, 2017; Kalyva, 2013; Kamtsios \& Lolis, 2016; Mouza \& Souchamvali, 2016; Tsakiridou, Kakalopoulou, Karamanidou, Papadopoulou, \& Tziouvara, 2014; Ziontaki \& Vissariou, 2014; Ziontaki, 2016). The same findings are laid out in research studies that focused on Spain and Portugal which were affected by the economic crisis as Greece was (Flores, 2013; Flores \& Ferreira, 2016; Lukaś \& Samardzic, 2014).

The aim of this study is, on the one hand, the investigation of the lived experiences of Greek primary school teachers as they are affected by the economic crisis in their everyday reality. In addition, an attempt is made at the investigation of the signification of the effect of the economic crisis on the educational and pedagogical work of these particular teachers.

This paper begins with the theoretical framework which is followed by the section containing the research questions and the methodology. Then the research findings are presented and analysed and the section containing the discussion and conclusions completes the paper.

\section{Theoretical framework}

This paper makes use of the theoretical framework of phenomenological sociology and in particular of Alfred Schutz's concepts. Phenomenology places emphasis on the individual and his social experiences as well as on the tangible social world of his daily life within which social actors co-exist and interact (Mann, 1983, p. 342). As Douglas (1980, as cited in Petmezidou, 1996, p. 281) characteristically states, phenomenological sociology is integrated in the category of theories of the "sociology of daily life".

The concepts of "lifeworld', "signification" and "intersubjectivity" from Schutz's theoretical framework are utilized in this paper.

The everyday world constitutes the fundamental, main and most powerful social reality for all social actors (Williams, 2001). It is understood as a socio-cultural world that is characterised by the intersubjectivity within which as much the daily actions of the individuals, as the forms of contact, communication and interaction that develop during their interaction with other social actors, co-exist (Santiago-Delefosse \& Carral, 2015, p. 1267; Schutz, Wagner, Psathas, \& Kersten, 1996, p. 26). The structure of the everyday world is characterised by structures which are seen as universal for all the social subjects and as having an unchanging organization and similar content (Eberle, 2015, p. 566). More precisely, as far as teachers are concerned, the everyday world is made up of two interconnected parts: their everyday and their professional reality. Their everyday reality amounts to their directly lived daily life, which at this particular time in Greece is being shaped in the context of the current recession. This reality is composed as much of the bonds of communication and interaction that they develop with their family, as it is of the activities they take part in together (trips, visits to the theatre and the cinema). It is also made up of the bonds and interactions that they develop with their wider social environment. The teachers' professional reality within the school environment, in the context of which they create bonds of communication, interaction and collaboration with their colleagues, their pupils as well as their pupils' parents, is also an integral part of their everyday world. According to the phenomenological approach, the world of everyday life, while it might appear to be a given, is, in reality, composed of the individuals' social action, as well as the social relationships they develop with other actors (Michalakopoulos, 1997, pp. 51-52). According to Schutz (1962, p. 208, 209, as cited in Ritzer \& Stepnisky, 2011, pp. 494, 495) the everyday world is constantly being modified, through the action of the social subjects, as well as the interaction they develop with the other social actors and in this way it can be reconstructed. Consequently, through their action as well as their lived experience, the teachers are in a position to reconstruct their daily and professional reality, as this is shaped by the economic crisis, with the main axis being the signification they assign to it. 
The process of signification is a structural element in the formation and interpretation of the social action of the actors (Natanson, 1970, p. 105). Signification refers to the way in which the social actors assign meaning to, analyse, interpret and understand the experiences they have in the context of their everyday social and educational reality (Dale, 1974, p. 54). In other words, signification is a process that provides the social subjects with the opportunity to analyse and subsequently interpret their lived social experiences, to assign meaning to them and then rank and categorize them. Hence, through signification, the teachers assign meaning to and interpret their lived experiences, based on the realities of the economic crisis in their daily and professional life. In this way a deeper understanding of the processes that are used for the organization of their social action, as well as for the formation of the social relationships and interactions that they develop with the other social actors in the social world of their everyday life is sought (Michalakopoulos, 1997, p. 53). The analysis and interpretation of the meaning that the teachers assign to their subjective experiences, together with their social actions and practices, form the context for the shaping and reconstruction of their social and educational reality (Schutz, 1962, p. 230, as cited in McLain, 1981, p. 113). Schutz (1964, p. 275) points out that the process of signification is subject to two distinctions. On the one hand, there is "subjective" signification which goes hand in hand with a personal manner of assigning meaning to everyday situations in one's social experience, highlighting the prominent position of the individual, as one with insider knowledge of the social experiences (Embree, 1991, p. 209). On the other hand "objective" signification appertains to the meaning that the same social experiences, actions and relationships have for the other people in one's everyday and professional reality beyond the individual who experiences them (Schutz, 1964, p. 275).

The concept of intersubjectivity is another concept from Schutz's theory that is of central importance. It concerns the common knowledge that unites the social actors, since through it they take on social reality through a set of characteristics and properties that are widely accepted by society at large (Dale, 1974, p. 57; Michalakopoulos, 1997, p. 54). So, the social world is characterised by an intersubjectivity which means it does not constitute a private environment for each individual, but rather a universal world that the social actors share (Schutz, 1987, p. 21, as cited in Van Haecht, 1998, p. 84; Miranda \& Saunders, 2003, p. 88). The everyday world links the individuals through common means of contact and communication, thought and understanding of social situations, as well as through common experiences and practices (Schutz, 1973, as cited in Ajiboye, 2012, p. 18). The existence of two or more individuals who live and carry out their daily social activities in a living and commonly experienced present is an essential prerequisite of intersubjectivity (Schutz, 1967, p. 104; Hall, 1977, p. 273). From this point of view, teachers constitute part of an intersubjective everyday and professional reality, within which they are connected to the other social actors (family, social milieu, colleagues, headteacher, pupils) through shared means of contact and communication, thought, and perception of social situations and experiences. Hence, through intersubjectivity, the teachers can construct as much their knowledge of the social world that surrounds them, which in this case is shaped in relation to the economic recession, as the entire Greek society (Mann, 1983, p, 342). Intersubjectivity in other words, is 'eavesdropping' on the social experiences of the teachers and is used as a guiding axis in the signification of the similarities and differentiations that exist in their sphere of consciousness, depending on the extent to which they are affected by the economic crisis (Drew, 2008, p. 76).

\section{Research Questions - Methodology}

In this paper we will be concerned with answering the following research questions:

1) What experiences do primary school teachers in Greece have regarding the consequences of the economic crisis for their everyday reality?

2) How do these teachers bestow meaning on their educational - pedagogical work as this is influenced by their lived experiences of the current economic crisis, in comparison with the pre-crisis period?

The research was carried out during the 2016-2017 school year in the city of Patras since, as research findings reveal, the area of Western Greece presents increased levels of poverty, unemployment and economic destitution as a result of the austerity measures that are in place (Ballas, Dorling, \& Henning, 2017).

'Convenience' sampling was used to carry out the research (Babbie, 2011, p. 290). Based on its principles, 20 primary schools to which we had easy access were selected from the total number of public primary schools in the area of Patras. The research sample was made up of 20 teachers ( 10 women, 10 men) who worked in these particular schools. They had an average of 18.6 years of teaching experience (the smallest number of years' experience was 10 , and the greatest was 26).

The research tool used was the semi-structured interview as through this the research subjects could express their thoughts and opinions on the effect of the economic recession on their daily and professional life freely (Robson, 1993, p. 237). The interviews were conducted using a digital tape recorder, after the consent of the teachers in the sample had been obtained. 
Then, qualitative content analysis was performed on the transcribed research material, with the theme as unit of analysis, aimed at the systematic processing, study and presentation of the research findings (Cohen, Manion, \& Morrison, 2005, p. 102). Based on the theoretical framework, the aim of the research and the research questions, we formed the following analysis categories:

A. The lived experiences of primary school teachers regarding the consequences of the economic crisis for their daily reality.

B. The significations of the primary school teachers regarding their educational - pedagogical work as it is influenced by their lived experiences, in comparison with the pre-crisis period.

B.1. The meaning the teachers assign to the approach to and support of pupils as a result of their lived experiences of the economic crisis.

\section{Presentation and analysis of the research results}

Next the findings of the qualitative content analysis are presented.

\section{A. The lived experiences of primary school teachers regarding the consequences of the economic crisis for their daily reality}

For Schutz (1962, pp. 229-234, as cited in Lengermann \& Niebrugge, 1995, p. 26), the everyday world sets out the teachers' direct and daily bio-environment. The approach to, examination and analysis of the social world of daily life is attempted through the experiences of the social actors. In this context and guided by the phenomenological perspective, we do not seek a superficial examination and analysis of the everyday practices and activities of the acting subjects but rather an in-depth analysis of the significations that they themselves assign to their social experiences, actions and behaviours (Dale, 1974, p. 54). So, as it is highlighted in the teachers' lived experiences, the consequences of the economic crisis are especially apparent in their everyday reality. More specifically, they themselves have suffered large reductions and cuts in their salary, which in some cases approach $45 \%$. A direct result of this situation is the fact that their buying power has decreased noticeably as they have limited their family expenses, such as: supermarket shopping, trips, eating out, as well as the purchase of clothing and footwear. In contrast, they concentrate solely on the purchase of the essential goods, necessary for their survival, as emerges from the following representative excerpts:

"My salary has been cut by between 350 and 400 euros a month. So your income is affected and if you have children and family you just try to meet basic needs and you leave shopping, travels and trips that you might have enjoyed before, to one side" (Interview - I.10.m - man).

"When our salary was higher, since my husband is a teacher too, we would eat out or we'd go shopping more easily. Now, we no longer do these things at all. We were even forced to sell one of our two cars just to make ends meet" (I.2.w - woman).

Everyday reality is the intersubjective environment of existence for the teachers, within which they engage in their daily activities. Within the social framework the teachers develop relationships and bonds of contact, communication and interaction with the other social actors (Berger \& Luckmann, 1966, pp. 65-66; Ritzer, 2012, p. 121). "The werelationship" according to Schutz's terminology, develops between the teachers, their family, and the individuals in their social environment. These relationships materialise in the directly experienced, living present, as this is formed under the influence of the economic crisis, a fact which has created other important difficulties in the family life of Greek teachers. So, they appear to have limited or given up their visits to the theatre or the cinema and have concentrated on the acquisition of their essential daily goods and the effort to ensure their children's well-being:

"With the cut in my salary, clothes, travels, holidays, trips are very limited. We have restricted ourselves to the essentials and given priority to the children" (I.1.w).

"I have three children and my husband and I have put aside our personal pleasures. We no longer go to the cinema so often and we give priority to the children" (I.4.w).

"We haven't been to the cinema for I don't know how many years, the same with the theatre...in other words we have cut back a lot on our spending. That is our daily life" (I.2.w).

From the analysis of the interview data it appeared that the relationships that the teachers develop with their social circle have not eroded due to the economic crisis. On the contrary, the teachers stated that the economic crisis has had a positive impact on the relationships they develop with their social circle and friends. This is because due to their reduced income, they have limited their nights out for food and entertainment and instead visit the homes of friends and relatives more frequently. As a result, the social bonds with their immediate family and friends are strengthened, as emerges from the following statements made by the teachers: 
"We no longer go out any more and we meet instead at each other's houses. We are now closer to our family friends and when we meet up, each of us brings whatever he can. For example, we all take something to parties, a plate of food....so I would say that the crisis has had a positive effect on relationships with our friends" (I.2.w).

"I'd say that the economic crisis has had a positive effect on people's relationships. In other words, we are closer to the other people and especially our friends" (I.1.w).

B. The primary school teachers' significations regarding their educational - pedagogical work as these are influenced by their lived experiences, in comparison with the pre-crisis period

The educational reality constitutes the everyday environment of the school and as such is made up of the acts of the social actors that are integrated in it and comprise an integral part of it. As a result of this it emerges that the structures of the educational reality are reconstructed, led as much by the acts and actions of the actors, as by their past lived experiences (Schutz, as cited in Lamnias, 2001, p. 191). The teachers' significations regarding their experiences are being developed within the everyday educational reality (Dale, 1974, p. 63). The subjective signification of experiences leads the teachers to understand the role their lived social experiences play in the world of their professional life (Schutz, 1962, p. 230, as cited in McLain, 1981, p. 113; Schutz, 2013, p. 48). The teachers' lived experiences, as these emerge from the effect of the economic recession on their everyday and professional reality, do not seem to have influenced the meaning the teachers assign to their educational and pedagogical role. Hence, the teachers assign weighty significance to the vocation they carry out and to their educational - pedagogical work, which does not appear to have altered in relation to the significance and meaning they assigned it during the pre-crisis period. This particular signification of their work stems from two factors. Firstly, from the prominent position the teachers assign to the institution of education, which they see as that institution which can shape able citizens capable of meeting the challenges of the economic crisis through the acquisition of the necessary knowledges and skills. And secondly, from the perception of their educational role as shapers of the pupils' personality. The following excerpts are representative of these findings:

"I believe that my educational work is just as important now as it was before the crisis because education is above everything else. It plays a very great role and is the means through which the economic crisis can be overcome" (I.3.w).

"It doesn't mean that because we have an economic crisis we are going to change anything educationally or pedagogically...we are still doing the same job. We are responsible for the children receiving the essential education. That is the least we can offer in this period of crisis" (I.2.w).

Consequently, based on the research findings, the teachers' lived experiences, driven by the realities of the economic crisis, have not influenced the meaning that they assign to their motivation and attitude towards the execution of their educational - pedagogical work, since they remain as strong as they were in comparison with the pre-crisis period. This is because the teachers place their pupils and their vocation to ensure their all-round cultivation and growth as their main motivation. Hence, the teachers "put to one side" the problems and difficulties that they experience in their everyday reality, as a direct outcome of the shrinking of their salary, and try to remain in possession of the same motives and the same powerful energetic attitudes towards the performance of their work, in comparison with the precrisis period:

"I still have the same attitude to work. I believe that I still have something to give and I enjoy what I do. I may see problems, mainly economic ones due to the reduction in my salary, but despite that I continue to work in the same way" (I.3.w.).

"I can say that I haven't cut any corners in the work I do as a teacher...none...perhaps because I never linked my salary with my profession" (I.2.w.).

Moreover, as emerges from the analysis of the research, the experiences of the economic crisis that the teachers live through, have not influenced the time they devote to preparing the lessons they are to teach. The teachers' greatest priority is the importance and value of their pedagogical role, as well as the responsibility that comes with imparting the necessary knowledges, values and skills to the pupils. Hence, it appears that the reductions and cuts in their salary do not constitute an obstacle for the teachers, and they continue to spend the same amount of time on the preparation of their lessons:

"For the preparation of my pedagogical work, the time I spend on lesson preparation remains the same, despite the economic crisis. That's because the conditions of the crisis have added other goals to my work, such as helping the children handle the difficult situations they experience due to the crisis" (I.6.w.).

B.1. The meaning that the teachers assign to the approach to and support of the pupils, as a result of their lived experiences of the economic crisis 
The research findings show that the experiences of the economic crisis that the teachers live through have strengthened the value they assign to their educational work during the approach to and the treatment of their pupils, as well as the relationships that they develop with them. The current economic recession and the strict austerity measures have created a number of problems and difficulties for Greek families and in this case the inability to obtain the essential daily goods as well as school supplies for their children, and the inability to find work in Greece. These difficulties inevitably influence the pupils' behaviour within everyday school life. So, two different views in terms of the opinions of the teachers on the approach to their pupils emerge. More precisely, it appears that many teachers approach and treat their pupils with greater compassion, sensitivity and understanding owing to the problems that they experience in their family environment. For that reason they devote more time to the children, discussing things with them and trying to support them, as emerges from the representative excerpts below:

"The time I devote to the children is greater than in the pre-crisis period. I need to support them because the crisis has affected them. They bring many of their family problems to school with them. Many of the children's parents are unemployed, looking for work and they can't feed their children and there are a lot of difficulties" (I.2.w.).

"I devote more time to the children because we are more sensitive when we know what is going on at home. When we know that there are economic problems, that the parents are out of work, and they are not able to buy the school supplies their children need. In such cases, we treat the pupils with greater sensitivity and we support them" (I.2.w.).

In addition, our research revealed that due to the difficulties that some pupils experience in their families, they display more aggression, creating tension in the space of the school. This creates a distance between some pupils and the teachers, influencing the relationships they develop with their teachers. In this case, the relationships that many teachers develop with their pupils are more distant in relation to the pre-crisis period:

"Unfortunately my relationships with my pupils have changed because a lot of children bring with them problems from home, which influence their behaviour in school. Chiefly it is the parents' economic problems that make the children more aggressive, more insecure..... all these things come out in the children's behaviour here at school, and as a result our relationships are more distant" (I.4.w.).

"The crisis has affected all the population so there is tension among the parents who are obviously facing economic problems. These tensions are brought into school by the children themselves who are a lot more aggressive and in certain cases more distant. I wouldn't say that our relationships with the pupils are as close as they were before the crisis”(I.1.w.).

\section{Discussion and Conclusions}

In this paper an examination of both the lived experiences of primary education teachers regarding the consequences of the economic crisis for their everyday reality, and of the way in which they signify their educational-pedagogical role under the influence of their lived experiences in comparison with the pre-crisis period, is attempted. From the study and analysis of the research results the following conclusions can be drawn:

Regarding the first research question, the primary school teachers' lived experiences reveal the consequences of the economic crisis in their everyday reality. Schutz points out that the social world of everyday life is composed of human actions and practices, and in this case, of the actions of teachers, as well as of the social relationships, actions and interactions that they develop with the other social actors (Jesus, Capalbo, Merighi, Oliveira, Tocantins, Rodrigues, \& Ciuffo, 2013, pp. 729-730). The research results showed that the teachers have suffered great reductions in their salary which in some cases reach $45 \%$. So, their buying power is noticeably reduced and they have limited their spending on clothing and footwear, travels, eating out and entertainment and they have concentrated on obtaining the basic goods that they require for day-to-day living. The findings of this research are in line with the results of Ziontaki's work (2016) where it became clear that the teachers' earnings were reduced drastically, negatively affecting their standard of living. From an inter subjective perspective, the teachers' comments reveal that the economic crisis has created a number of difficulties in their families. So, they have limited their spending on travel and entertainment as they have made their children's well-being their top priority. At the same time, the teachers have drastically reduced the events and activities they took part in in the past with their families, such as excursions, and visits to the theatre and cinema. Indeed it appears that the interaction that develops between the social actors is a structural element in the creation of an intersubjective world in which the actors interact with and understand the position of the others in the present and in a commonly experienced place and time (Petmezidou, 1996, p. 16). The findings of Chalari's research (2016b) are in line with the findings of this paper since they highlight the fact that the economic crisis has greatly affected the daily life of Greek primary school teachers and has reshaped their way of life. In addition this research showed that the economic crisis has a positive impact on the teachers' communication and interaction with individuals in their social circle. 
This is because their reduced income leads the teachers to meet up in the homes of relatives and friends, something that strengthens the social relationships between them. As far as the second research question is concerned, the research findings underlined the meaning that primary school teachers attach to their educational - pedagogical work due to the effect of their lived experiences, in comparison with the pre-crisis period. In the context of the educational reality, the importance of signification is revealed, as it focuses on the action and behaviour of the teachers, as well as on the way they assign meaning to their social and professional experiences and actions (Schutz, 1964, p. 274). More specifically, the experiences that the teachers in the sample have lived through in their everyday and professional reality as a consequence of the economic crisis, do not appear to have affected the vocation they follow. This is because the lived experiences of the teachers during the period of the economic crisis do not seem to have changed the meaning that they attach to the importance of their educational - pedagogical work in comparison with the way in which they worked in the pre-crisis period. So the interpretation and meaning that the teachers assign to their educational work is founded on the weighty importance that they attach to the institution of education, which constitutes the means for the formation as much of the pupils' personality, as of their own role. Consequently, through the teachers' subjective significations, the powerful motives that they continue to possess for the implementation of their work are highlighted. These particular research findings are confirmed by the corresponding research result of Tsakiridou et al. (2014) where it appeared that the teachers' salary cuts have not affected their productiveness and their effort to maintain their teaching work at a satisfactory level. In contrast, in Kossyva's research (2017) it appears that the consequences of the economic crisis for the teachers' everyday reality reduced their interest in performing their educational work.

At the heart of phenomenological - sociological interest is the meaning that the actors assign to their social experiences and to their action, which is formed through these significations (Ritzer, 1975, as cited in Petmezidou, 1996, p. 282). The research results showed that the teachers' lived experiences of economic crisis increased the amount of time they devoted to helping and supporting their pupils. This is because the economic crisis has created serious problems and difficulties in the pupils' families, affecting their behaviour in school. What's more, the teachers spend the same amount of time on preparing their lessons in comparison with the pre-crisis period as they believe that their profession is significant for the shaping of their pupils. So, the meaning that the teachers assign to their lived experiences does not appear to influence the way they think and act or the way they assign meaning to their professional position and daily life (Schutz, 1962, p. 2, as cited in Embree, 1991, p. 208). The problems that occur in the pupils' families affect their behaviour at school, and as a consequence in certain cases, the teachers' approach to and treatment of the pupils is based more on compassion, sensitivity, understanding and the provision of help and support in comparison with the pre-crisis period. However, there were cases of teachers in the sample who stated that their pedagogical relationship with their pupils was negatively affected due to the latter's bad behaviour as a result of the transfer of family problems to the microcosm of the school.

Although the results of this research cannot be generalised, they are still useful since they highlight the effect of the teachers' lived experiences on the meaning that they themselves attach to their educational role in relation to the precrisis period. As an extension of this paper it would be useful to investigate the meaning that teachers in compulsory education in Greece attach to their educational work as a consequence of the economic crisis. This is because a comparative examination of the results would be interesting in order to depict the level of education most affected by the economic crisis.

\section{References}

Ajiboye, O.E. (2012). Social phenomenology of Alfred Schutz and the development of African sociology. British Journal of Arts and Social Sciences, 4(1), 12-25.

Akrivou, E., Bonoti, F., \& Dermitzaki, E. (2016). School age children's views on the economic crisis. Preschool \& School Education, 4(2), 305-322.

Babbie, E. (2011). Introduction to Social research. Athens: Kritiki.

Ballas, D., Dorling, D., \& Henning, B.D. (2017). Analysing the regional geography of poverty, austerity and inequality in Europe: A human cartographic perspective. Regional Studies, 51(1), 174-185.

Berger, P.L., \& Luckmann, T. (1966). The Social Construction of Reality: A Treatise in the Sociology of Knowledge. New York: Doubleday.

Botou, A., Mylonakou-Keke, I., Kalouri, O., \& Tsergas, N. (2017). Primary School Teachers' Resilience during the Economic Crisis in Greece. Psychology, 8(1), 131-159.

Chalari, M. (2016a). Crisis, austerity and its impact on education in Europe and Greece. Educate, 16(1), 15-24.

Chalari, M. (2016b). Teachers' experiences of and responses to the recent socio-economic crisis in Greece and the new challenges that have stemmed from it. Education in the North, 23(2), 154-160. 
Cohen, L., Manion, L., \& Morrison, K. (2005). Research Methods in Education. London: Routledge.

Dale, R. (1974). Phenomenological perspectives and the sociology of the school. In M. Flude, \& J. Ahier (Eds), Educability, Schools and Ideology (pp. 53-69). London: Routledge.

Dreher, J. (2003). The symbol and the theory of the life-world: "The transcendences of the life-world and their overcoming by signs and symbols". Human Studies, 26(2), 141-163.

Drew, N. (2008). The primacy of intersubjectivity. Advances in Nursing Science, 31(1), 74-80.

Eberle, T.S. (2015). Exploring Another's Subjective Life-World: A Phenomenological Approach. Journal of Contemporary Ethnography, 44(5), 563-579.

Embree, L. (1991). Notes on the specification of "meaning" in Schutz. Human Studies, 14(2-3), 207-218.

Flores, M.A. (2013). Conditions for Teacher Professional Development and Leadership in a Context of Austerity: A 3year Study in Portugal. In S.M. Kwiatkowski \& J. Madalińska-Michalak (Eds.), Educational LeadershipContemporary Challenges (pp. 167-186). Warsaw: Wolters Kluwer.

Flores, M.A., \& Ferreira, F.I. (2016). Education and child poverty in times of austerity in Portugal: implications for teachers and teacher education. Journal of Education for Teaching, 42(4), 404-416.

Hall, J.R. (1977). Alfred Schutz, his critics, and applied phenomenology. Cultural Hermeneutics, 4(3), 265-279.

Hatziparadeisi, A. (2017). Economic crisis and parents' educational choices. (Postgraduate Dissertation). Ioannina: University of Ioannina.

Jesus, M.C.P., Capalbo, C., Merighi, M.A.B., Oliveira, D.M., Tocantins, F.R., Rodrigues, B.M.R.D., \& Ciuffo, L.L. (2013). The social phenomenology of Alfred Schütz and its contribution for the nursing. Revista da Escola de Enfermagem da USP, 47(3), 728-733.

Kakana, D.M., Garagouni-Araiou, F., Theodosiou, S., Manoli, P., Mavidou, A., Rousi-Vergou, H., Hatzopoulou, K., Androusou, A., Avgitidou, S., \& Tsafos, B. (2016). The TOCSIN Programme: dimensions and effects of the economic crisis in primary education. Dialogues! Theory and Action in the Sciences of Education, 2, 78-102.

Kalyva, E. (2013). Stress in Greek Primary Schoolteachers Working Under Conditions of Financial Crisis. Europe's Journal of Psychology, 9(1), 104-112.

Kamtsios, S., \& Lolis, T. (2016). Are Greek teachers experiencing professional burnout? The role of demographic features and daily stress inducing stimuli. Scientific Yearbook of the Department of Early Childhood Education at the University of Ioannina, 9(1), 40-87.

Kossyva, K. (2017). Problems in the quality of primary education that emerged as a result of the poverty of the average Greek household due to the economic crisis (Master thesis). Athens: Higher Educational Institute of Piraeus

Lamnias, K. (2001). Sociological theory and education. Distinct approaches. Athens: Metaichmio Publications.

Lengermann, P.M., \& Niebrugge, J. (1995). Intersubjectivity and domination: A feminist investigation of the sociology of Alfred Schutz. Sociological Theory, 13(1), 25-36.

Lukaś, M., \& Samardzic, D. (2014). Impact of Teacher's Income on Student's Educational Achievements. In Conference Proceedings. Conference on Psychology and Psychiatry, Sociology and Healthcare, Education, Bulgaria, 1-9 September 2014 (Vol. 3, pp. 383-390). DOI: 10.5 593/sgemsocial2014/B 13/S3.051

Magaliou, S., \& Haniotakis, N. (2014). Primary school pupils' views on the economic crisis. In M. Tzekaki \& M. Kanatsouli (Eds), Proceedings of the Panhellenic Conference with International Participation: Reflections on Childhood. (pp. 1454-1458). Thessaloniki: School of Early Childhood Education, Aristotle University of Thessaloniki.

Mann,M.(1983).The Macmillan Encyclopedia of Sociology. London: Macmillan Press.

Matsaganis, M., \& Leventi, C. (2014). Poverty and inequality during the Great Recession in Greece. Political Studies Review, 12(2), 209-223.

McLain, R. (1981). The postulate of adequacy: phenomenological sociology and the paradox of science and sociality. Human Studies, 4(1), 105-130.

Miranda, S.M., \& Saunders, C.S. (2003). The social construction of meaning: An alternative perspective on information sharing. Information Systems Research, 14(1), 87-106.

Michalakopoulos, G.S. (1997). The school and the classroom. Sociological Prospects. Thessaloniki: Kyriakidis Publications.

Mouza, A.M., \& Souchamvali, D. (2016). Effect of Greece's New Reforms and Unplanned Organizational Changes on the Stress Levels of Primary School Teachers. Social Indicators Research, 128(3), 981-994.

Natanson, M. (Ed.) (1970). Phenomenology and Social Reality: Essays in Memory of Alfred Schutz. Netherlands: The Hague.

Ötker-Robe, I., \& Podpiera, A.M. (2013). The Social Impact of Financial Crises: Evidence from the Global Financial Crisis. Washington DC: The World Bank. 
Papatheodorou, C., \& Papanastasiou, S. (2017). The state of the children in Greece. The children of crisis. Athens: UNICEF.

Petmezidou, M. (1996). Contemporary Sociological Theory. Structural-functionalism, Critique of positivism, Symbolic interactions, meaning and interpretation. University publications of Crete.

Poeschl, G., Valentim, J.P., \& da Silva, B.P. (2015). The Thousand Shades of the Financial and Economic Crisis: a Study of the Social Representations of the Crisis in Portugal. The Spanish Journal of Psychology, 18(77), 1-10.

Ritzer, G., \& Stepnisky, J. (2011). The Wiley-Blackwell Companion to Major Social Theorists. Volume I. Classical Social Theorists. Massachusetts: Blackwell Publishing.

Ritzer, G. (2012). Contemporary Sociological Theory. Athens: Kritiki Publications.

Robson, C. (1993). Real world research. A resource for social scientists and practitioners - researchers. Massachusetts: Blackwell Pushers.

Santiago-Delefosse, M., \& Carral, M.D.R. (2015). The life-world and its multiple realities: Alfred Schutz's contribution to the understanding of the experience of illness. Psychology, 6(10), 1.265-1.276.

Schutz, A. (1964). Collected Papers II: Studies in Social Theory. The Hague: Martinus Nijhoff.

Schutz, A. (1967). The Phenomenology of the Social World. Evanston, Illinois: Northwestern University Press.

Schutz, A. (2013). Life forms and meaning structures. In M. Barber (Ed.), Collected Papers VI. Literary Reality and Relationships. (pp. 37-115). Dordrecht: Springer.

Schutz, A., Wagner, H., Psathas, G., \& Kersten, F. (Eds) (1996). Alfred Schutz. Collected Papers. Volume IV. New York: Springer.

Tsakiridou, E., Kakalopoulou, G., Karamanidou, A., Papadopoulou, O., \& Tziouvara, M.R. (2014). Economic crisis and education in Greece. MENON: Online Journal of Educational Research, 3, 5-25.

Van Haecht, A. (1998). L'école à l'épreuve de la sociologie. Questions à la sociologie de l'éducation. Paris: De Boeck.

Vasilopoulou, S., Halikiopoulou, D., \& Exadaktylos, T. (2014). Greece in Crisis: Austerity, Populism and the Politics of Blame. JCMS: Journal of Common Market Studies, 52(2), 388-402.

Wagner, H.R. (1970). Alfred Schutz on Phenomenology and Social Relations. Selected Writings. Chicago: The University of Chicago Press.

Williams, J. (2001). Phenomenology in Sociology. In N.J. Smelser \& P.B. Baltes (Eds), International Encyclopedia of the Social \& Behavioral Sciences (pp. 11361-11362). Pergamon Elsevier.

Zavras, D., Tsiantou, V., Pavi, E., Mylona, K., \& Kyriopoulos, J. (2013). Impact of economic crisis and other demographic and socio-economic factors on self-rated health in Greece. European Journal of Public Health, 23(2), 206-210.

Ziontaki, Z. (2016). Teachers, crisis and education: 'material poverty' and 'moral collapse'. International Journal of Employment Studies, 24(2), 109-130.

Ziontaki, Z., \& Vissariou, A. (2014). The consequences of the financial crisis in the educational praxis: A content analysis in the light of critical pedagogy. International Journal of Educational Policies, 8(2), 61-78. 